УДК 338.24:339.74 (477)

DOI 10.30970/vir.2019.47.0.10990

\title{
DEMOGRAPHY AND THE CONTEXT OF HEALTH IN PALIATIVE CARE
}

\author{
Jaroslav Stančia \\ Comenius University in Bratislava, Faculty of Education
}

Richard Didič, Róbert Babel’a

Institute of Health Care Disciplines, St. Elizabeth University, Bratislava

\section{Martin Samohýl}

Comenius University in Bratislava, Institute of Hygiene, Faculty of Medicine

The aim of our work was to analyse the tendencies of hospitalization in the palliative care wards and trends in the consumption of analgesics prescribed by geriatrics. Analysed was the consumption of 21,302 most common diagnoses in the hospitalized patients at palliative care wards in the period from 1/2016 to 12/2017. The data were based on the request provided by Všeobecnázdravotnápoist'ovňa, a.s. (health insurance company). In the trend analysis was used APC (annual percentage change indicator), and for statistic analysis was used IBM SPSS Statistics. Further was analysed the consumption of 12,888 of the most commonly prescribed analgesics by geriatrics in the period from $1 / 2016$ to $12 / 2017$. In 2017 was found the significant decrease in hospitalized patients in palliative care wards with the diagnoses as follows: tumours (APC -22.9 \%), mental and behavioural disorders (APC -4.6 \%), disorders of nervous system (APC -26.3\%), skin and subcutaneous tissue diseases (APC $-35.1 \%$ ), respiratory disorders (APC $-35.4 \%$ ), shoulder and arm fractures (APC - $25.6 \%$ ), multiple area injuries (APC -54, $5 \%$ ) and later consequences of lower limb injuries (APC -58.3\%). The aging of the population brings a great challenge to ensure the adequate financial, human and other material resources to ensure the sufficient economic productivity and promote the status of active aging in the context of human dignity and fundamental principles of humanism that should not disappear from our society.

Key words: demography; noncommunicable diseases; palliative care; population ageing; public health.

(C) Stančia Jaroslav, Didič Richard, Babel’a Róbert, Samohýl Martin, 2019 


\section{Introduction}

The complex health state of population, and also the health care in Europe has been improving (Jakab, 2011). Life expectancy at birth just reflects the fact, that since 1980 it increased by 5 years, in 2010 it reached 75 years, and further is expected to reach approximately 81 years of age by 2025 (Jakab, 2011). Life expectancy at birth is one of the main indicators bound with health status of population reflecting the standards of living, the lifestyle of population, better education and access to health services (OECD - https://data.oecd.org/healthstat/life-expectancy-at-birth.htm, retrieved: 17.01.19, 20:32).

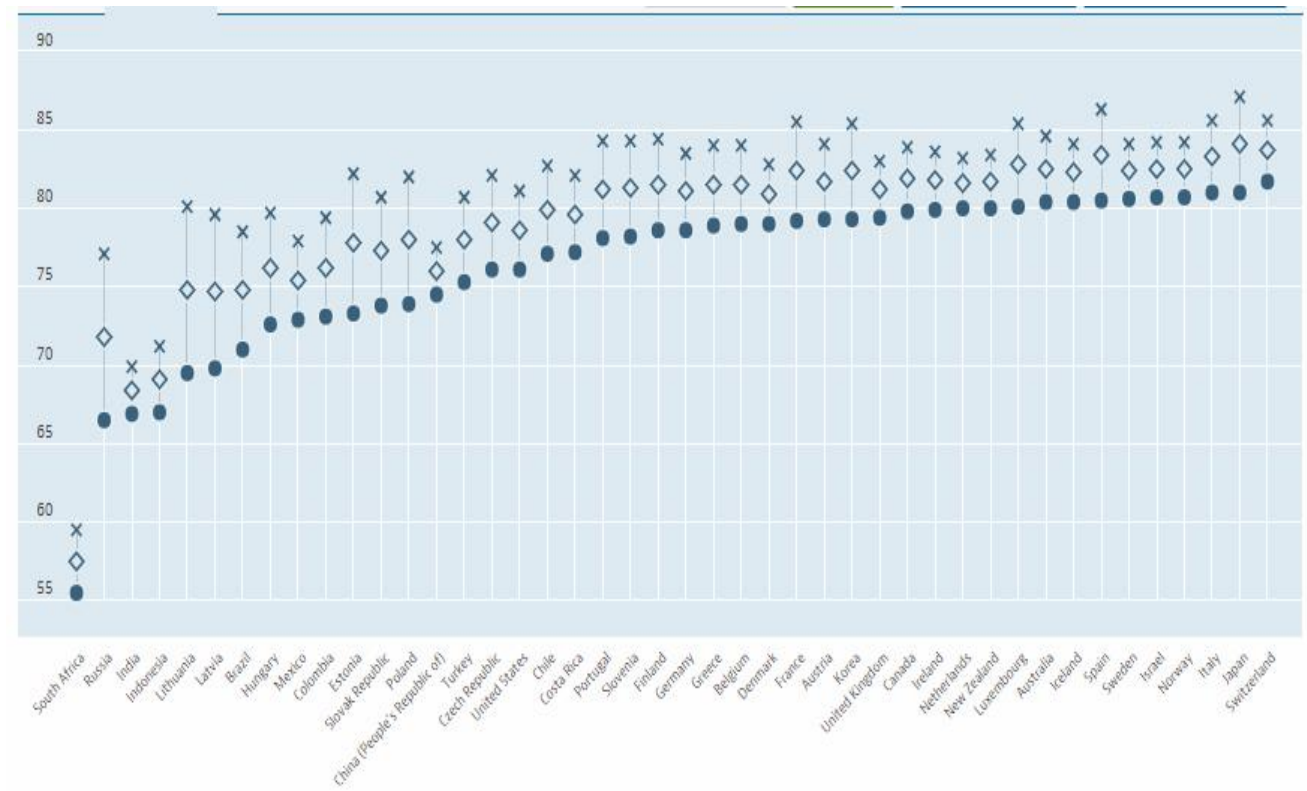

Figure1. LIfeexpectancyatbirth(OECD - https://data.oecd.org/healthstat/lifeexpectancy-at-birth.htm, : 17.01.19, 20:32)

Since the middle of $19^{\text {th }}$ century, the population of Europe has been more than doubled, but in recent decades it was not less significant. In 1960, the EU - 27 states gained the level of 415 million people, but since then the figure has increased by 80 million.

Expected is the growth of EU - 15category, in the given regions, where the average life expectancy will continue to grow, and by 2050 it is expected to reach 85 years of age (Jakab, 2011). For comparison, the Commonwealth of Independent States expects reaching the level of 75 years, what is the level seen in Europe 45 years ago as well as with the EU - 15 level 65 years ago (Jakab, 2011).

According to Eurostat projections in the period between $1^{\text {st }}$ January 2016 and $1^{\text {st }}$ January 2080 , the total amount of EU -28 population is expected therise by $1.7 \%$, the total number ofpopulation will increase by 8.5 million people (https: //ec.europa. eu, 2018). Population is projected to reach its peak around 2045, and reach 
529 million people, what is the increase of 18.8 million compared with the situation in January 2016 (https://ec.europa.eu, 2018). Subsequently the gradual decline in the number of inhabitants foreseen in early 2080 is 519 million as the total amount of population (https://ec.europa.eu, 2018).

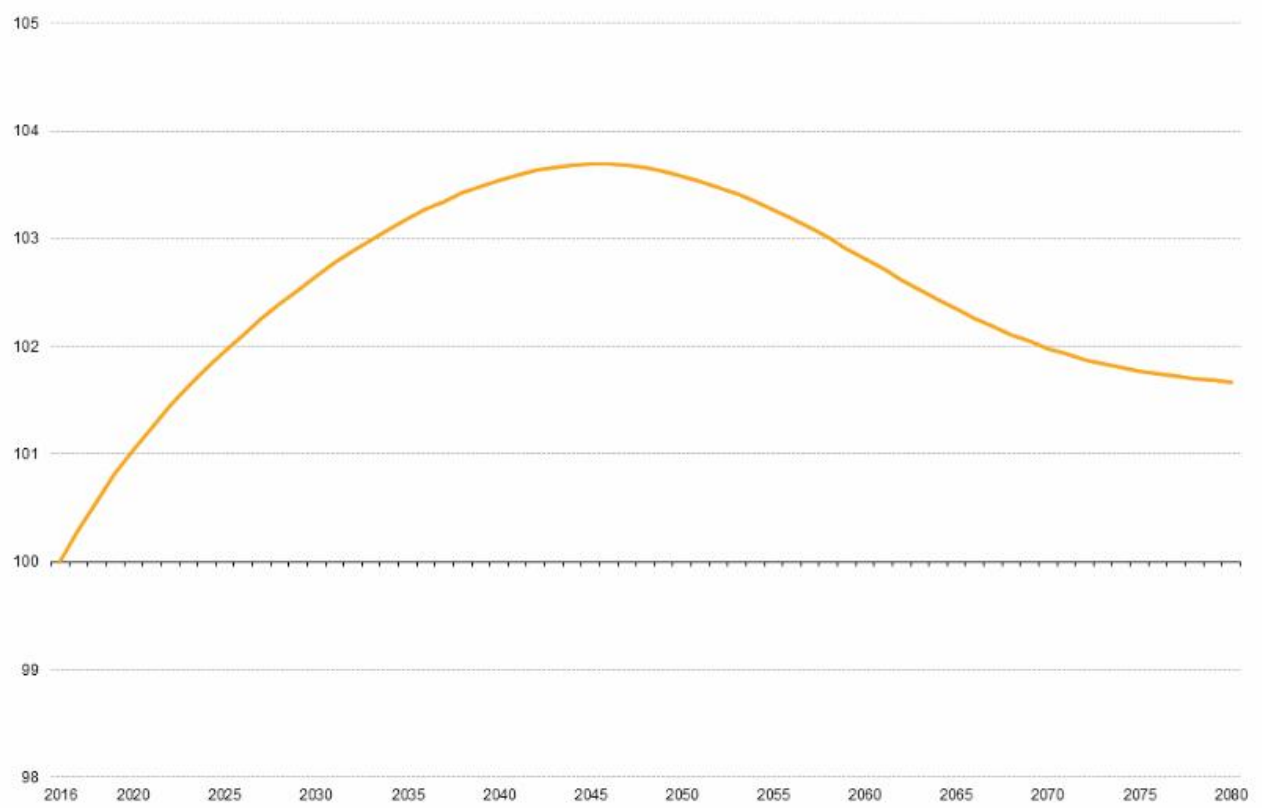

Figure2. Developmentof EU population, (https://ec.europa.eu, 2018).

Further is expected gradual decrease of children, both in relative and absolute terms, from $15.6 \%$ in early 2016 (79.5 million) to $15.2 \%$ in 2080 (78.9 million). (https://ec.europa.eu, 2018).

The share of EU - 28 working-age population has beendeclining, it will drop from 333 million to 288.4 million by 2080 (https://ec.europa.eu, 2018). The overall decline in the working age of the next 6.5 decades is projected to 44.5 million people, and by 2035 it is projected thedecrease below $60 \%$ in the working age group with further remaining below by 2080 (https: //ec.europa.eu, 2018). The trend points to the additional 53.3 millionof older people by 2080 (https://ec.europa.eu, 2018). 
Jaroslav Stančia, Richard Didič, Róbert Babela, Martin Samohýl

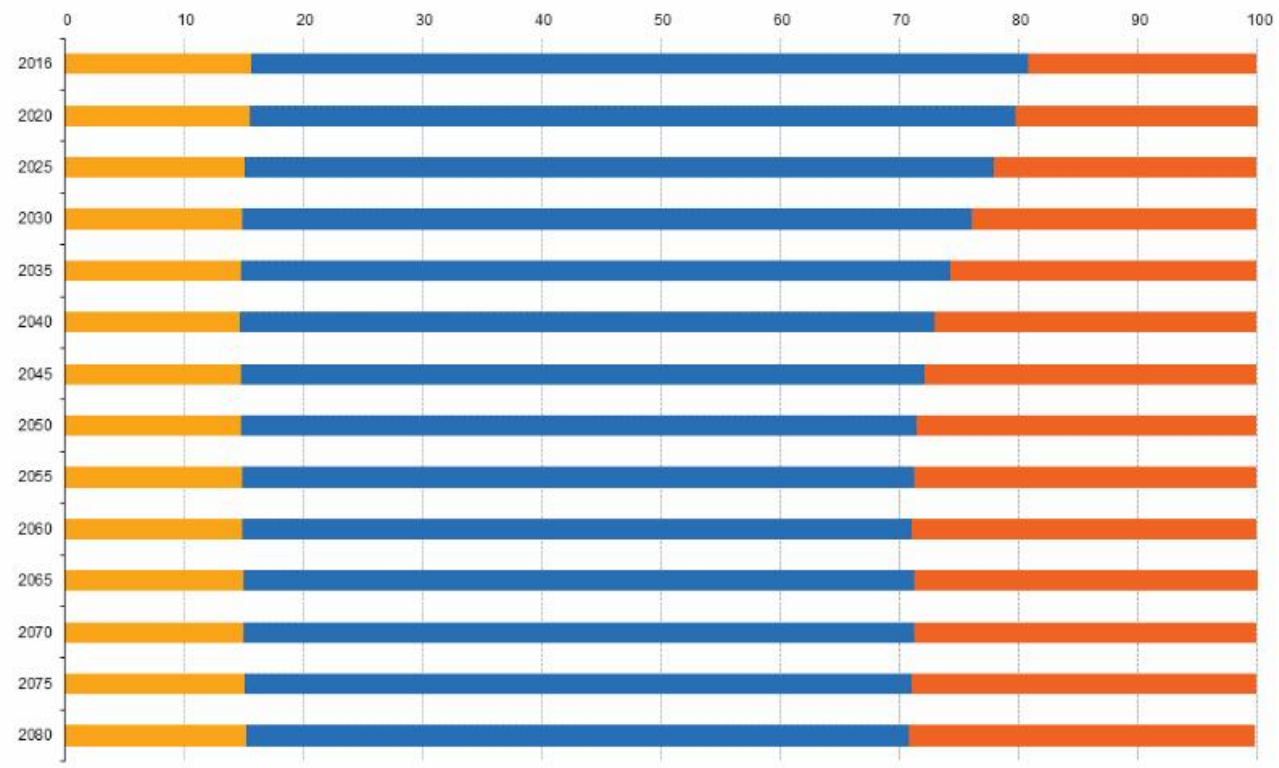

Figure 3. Age structure of population, EU 28 development 2016-2080

(Source: https://ec.europa.eu, 2018)

Key to the picture: Age structure of population, the EU's 28 development from 2016 to 2080: yellow stripes (0-14 years of age), blue stripes (the population in working age 16-64), orange stripes (65 and over).

WHO considers the population agingas the main reason of changedaetiology inpopulation dying, what is not the result of infectious diseases, but the result of noncommunicable diseases (Suzman et al., 2011).

The following graph illustrates the evolution of global population structure, where is visible the state in 1950, when the population of children clearly exceeded the adult population, but by 2050 is expected absolutely opposite ratio inpopulation scale.

Economic prices as well as the social costs are rising steadily together with the development of chronic diseases such as cardiovascular diseases, diabetes, various types of oncological diseases what can considerably influence complex economic results. (Global Health and Aging - WHO, NIA, NIH, U.S. Department of Health and Human Services, 11-7737 October 2011, retrieved from : https://www.who.int/ageing/publications/global_health.pdf). 


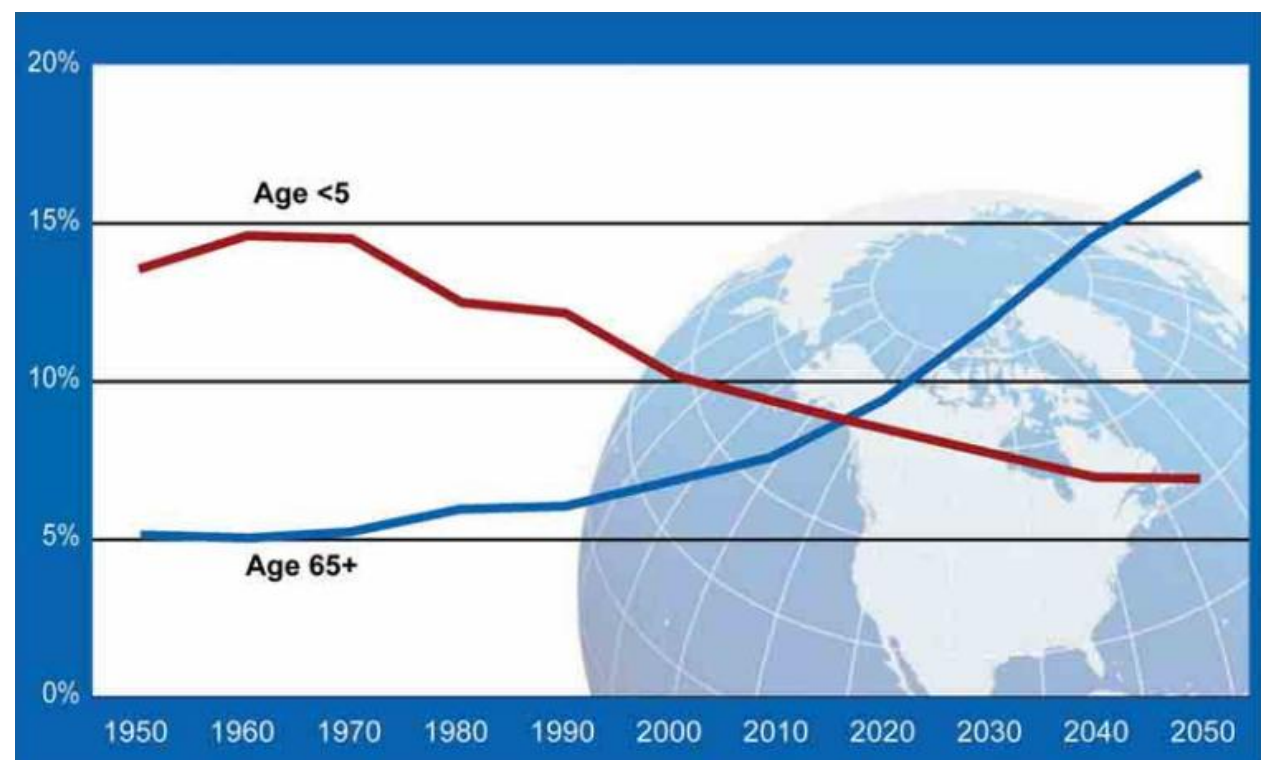

Figure4. Development of global population 1950-2050 (Source: United Nations.

World Population Prospects: The 2010 Revision. Available at:

http://esa.un.org/unpd/wpp in Global Health and Aging - WHO, NIA, NIH, U.S.

Department of Health and Human Services, 11-7737 October 2011, retrieved from : https://www.who.int/ageing/publications/global health.pdf)

The aging index in Slovakia is expected to exceed the threshold of 100 before 2025 , it means that for the first time in the history will be the population in productive age over 16 higher than the population in the reproductive age (Blaha, Vaňo, 2007). In 2025, the male aging index will be 102, and with post-productive women it will be more than 150 in 100 women in pre-productive age (Blaha, Vaňo, 2007). The oldest people share over 80 will increase by more than one percentage point to $3.7 \%$ by 2025 (Blaha, Vaňo, 2007). The population aging in Slovakia will be one of the most intensive ones within the whole European Union (Blaha, Vaňo, 2007).

WHO notes that in 2008, 57 millionof total deaths, were $63 \%$ representing 36 million that were caused by chronic diseases such as cardiovascular diseases, diabetes, cancer and chronic respiratory diseases, while worldwideis assumed growing of the annual proportion of deaths due to chronic diseases(WHO, 2010). In 2016, from the total amount of 56.9 millionof deaths, 40.5 million (71\%), were caused by chronic illness (https://www.who.int/gho/ncd/mortality_morbidity/en/, retrieved: 3.2.19 23:25).

The following graph(2012)reflectsgraphicpresentation of the worldwide deaths and proportions of aetiology, where the source of information and graphic presentation was taken from the publication: Global Status Report on Non-communicable Diseases 2014 ISBN 978924156485 4, WHO 2014.

The graph shows the causes of death in the population and the deaths of chronic diseases. 


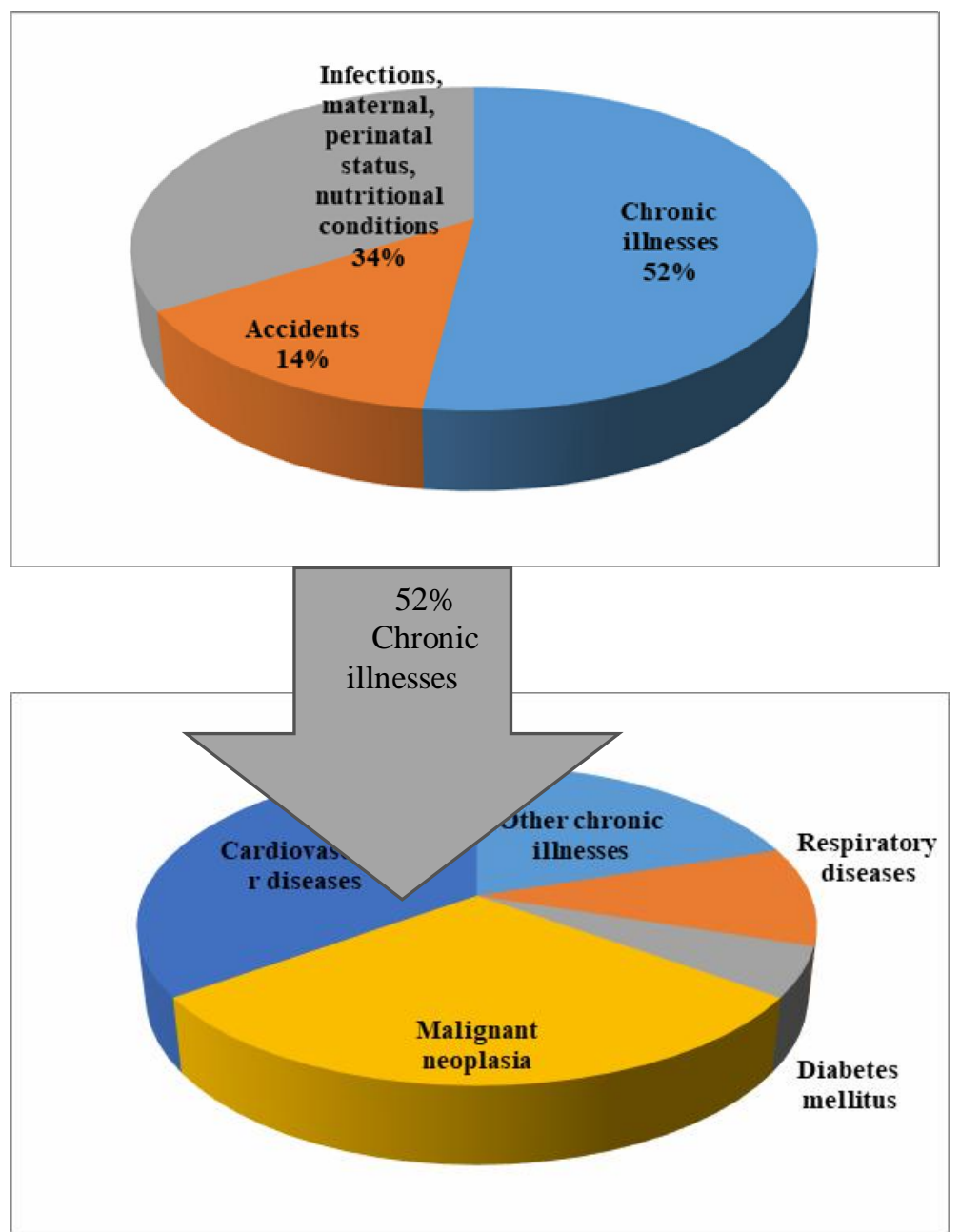

Figure 5. Proportion of worlwide deaths based on aethiology - year 2012 (WHO, 2014).

The effects of diseases on human life can be quantified by the means of DALYs, which means Disability Adjusted Life Years, WHO (2018) defines them as the sum of years of life lost due to premature death and the sum of lost years of productive life due to disability (https://www.who.int/mental_health/management/depression/ daly/en/).

DALYs is one of the techniques used for economic evaluation in the health sector with one essential goal - to improve the efficiency of resources allocation (Babel'a, 2008). 


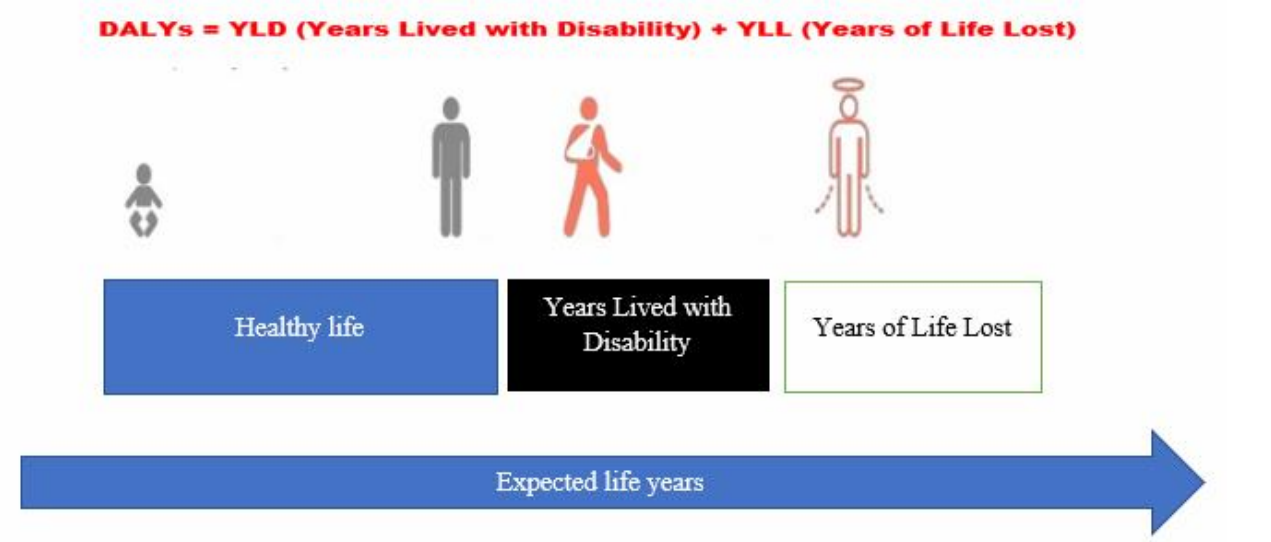

Figure 6. DALYs - explanation (modified

byhttp://www.publichealthnotes.com/daly-disability-adjusted-life-years. - retrieved 10.02.19, 10:05)

Based on the study on Global Burden of Disease from 2010,Ondruš et al. (2015) states that $23.1 \%$ (574 mln. DALYs) attributed to the global burden of diseases in people older than 60 years. The biggest contributor in the group of population was createdby cardiovascular diseases $(30,3 \%)$, then malignant diseases $(15.1 \%)$, chronic respiratory diseases $(9.5 \%)$, musculoskeletal diseases $(7.5 \%)$ and neurological and mental diseases $(6.6 \%)$.

The effects of aging connected with the quality of health care should be viewed through the optics of education. Stareček et al. (2018) reports the consequence as the low number of applicants for higher education, and then limited qualified staff for future. Jurenka et al. (2018) literally states that secondary and high school students encounter the exponential lack of students interest. Connected with this, it is necessary to realize that many times the structure of Slovak school graduates does not correspond to the market needs (Stareček et al., 2018).

\section{Aim of the work}

As it was already outlined, the number of post-productive population has been increasing, and alsothe prevalence of chronic illnesses. Known is that pain and polypharmacotherapy arethe basic manifestations of old age diseases, where analgesics are the essentials. The consumption of drugs is the impact of age associated with polymorbidity, manifested as the economic burden not only for the health system but also for the patient himself. Connected with that were analysed the tendencies of hospitalization in the palliative care wards and trends in the consumption of analgesics prescribed by geriatrics.

\section{Methodology}

Analysed was the consumption of 21,302 most common diagnoses in the hospitalized patients at palliative care wardsin the period from 1/2016 to 12/2017. The 
Jaroslav Stančia, Richard Didič, Róbert Babel'a, Martin Samohýl

data were based on the request provided by Všeobecnázdravotnápoist'ovňa, a.s.(health insurance company).

In the trend analysis was used APC (annual percentage change indicator), and for statistic analysis was used IBM SPSS Statistics. The indicator of annual percentage change was calculated as follows: $\mathbf{A P C}=\mathbf{x}^{1} * \mathbf{1 0 0} / \mathbf{x}^{2}-\mathbf{1 0 0}$, where $\mathrm{x}^{1}$ is the number of hospitalized patients in the palliative care ward in 2017 and $x^{2}$ is the number of hospitalized patients in the palliative care ward in 2016.

Further was analysed the consumption of 12,888 of the most commonly prescribed analgesics by geriatrics in the period from $1 / 2016$ to $12 / 2017$.

The annual percentage change was calculated as follows: $\mathbf{A P C}=\mathbf{x}^{1} * \mathbf{1 0 0} / \mathbf{x}^{2}-$ 100, where $x^{1}$ is the number of prescribed analgesics in 2017 and $x^{2}$ is the number of prescribed analgesics in 2016.

\section{Results}

Table 1

Amount of hospitalized patients ( $\mathrm{n})$ in palliative ward with selected diagnoses $(\mathrm{n}=$ 21,302) by period 2016-2017 and APC (\%)

\begin{tabular}{|l|c|c|c|}
\hline \multicolumn{1}{|c|}{ Selected diagnoses } & $\mathbf{2 0 1 6}(\mathrm{n})$ & $\mathbf{2 0 1 7}(\mathrm{n})$ & $\mathbf{A P C}(\%)$ \\
\hline $\begin{array}{l}\text { Subjective and objective symptoms, } \\
\text { abnormal clinical and laboratory findings }\end{array}$ & $\mathbf{2 3 4}$ & $\mathbf{2 5 8}$ & $\mathbf{1 0 , 3}$ \\
\hline Breathing disorders & 48 & 31 & $\mathbf{- 3 5 , 4 ^ { * }}$ \\
\hline Abdomen and pelvis pain & 21 & 17 & $-19,0$ \\
\hline Somnolence, sopor and coma & 138 & 179 & $\mathbf{2 9 , 7}$ \\
\hline Non-classified shock & 9 & 14 & 55,6 \\
\hline $\begin{array}{l}\text { Injury, poisoning and some other external } \\
\text { causes }\end{array}$ & 717 & 795 & $\mathbf{1 0 , 9} *$ \\
\hline Rib, sternum and thoracic spine fractures & 40 & 47 & 17,5 \\
\hline Lumbar spine and pelvis fracture & 122 & 146 & $\mathbf{1 9 , 7} *$ \\
\hline Shoulder and arm fracture & 43 & 32 & $\mathbf{- 2 5 , 6 ^ { * }}$ \\
\hline Femur fracture & 351 & 392 & $\mathbf{1 1 , 7} *$ \\
\hline Injuries affecting multiple body parts & 33 & 15 & $\mathbf{- 5 4 , 5} * *$ \\
\hline $\begin{array}{l}\text { Complication caused by } \\
\text { orthoprosthesis, implant or transplant }\end{array}$ & 45 & 75 & $\mathbf{6 6 , 7}$ * $^{*}$ \\
\hline Late consequences of head injury & 13 & 24 & $\mathbf{8 4 , 6}$ ** \\
\hline Late consequences of lower limb injury & 24 & 10 & $\mathbf{- 5 8 , 3} * *$ \\
\hline Infectious and parasitic disease & 64 & 56 & $-12,5$ \\
\hline Tumours & 131 & 101 & $\mathbf{- 2 2 , 9 *}$ \\
\hline $\begin{array}{l}\text { Melanoma and other skin malignant } \\
\text { tumours }\end{array}$ & 38 & 33 & $-13,2$ \\
\hline $\begin{array}{l}\text { Malignant tumours of mesothelium and soft } \\
\text { tissues }\end{array}$ & 23 & 18 & $-21,7$ \\
\hline Benigntumours & 19 & 21 & 10,5 \\
\hline Mental andbehavioural disorders & 3639 & 3472 & $\mathbf{- 4 , 6 *}$ \\
\hline
\end{tabular}




\begin{tabular}{|l|c|c|c|}
\hline $\begin{array}{l}\text { Schizophrenia, schizotypal and delusional } \\
\text { disorders }\end{array}$ & 11 & 11 & 0,0 \\
\hline Nervous system diseases & 38 & 28 & $\mathbf{- 2 6 , 3 ^ { * }}$ \\
\hline Circulatory diseases & 423 & 418 & $-1,2$ \\
\hline Chronic ischemic heart disease & 247 & 259 & 4,9 \\
\hline Cardiac arrest & 28 & 33 & 17,9 \\
\hline Other cerebrovascular diseases & 138 & 116 & $-15,9$ \\
\hline Respiratory diseases & 141 & 157 & 11,3 \\
\hline Influenza and pneumonia & 116 & 137 & 18,1 \\
\hline Other lung diseases & 10 & 9 & $-10,0$ \\
\hline Other respiratory system disease & 12 & 6 & $\mathbf{- 5 0 , 0}$ \\
\hline Skin and subcutaneous tissue diseases & 97 & 63 & $\mathbf{- 3 5 , \mathbf { 1 } ^ { * }}$ \\
\hline Musculoskeletal and connective tissues & 38 & 37 & $-2,6$ \\
\hline
\end{tabular}

$* \mathrm{p}<0,05 ; * * \mathrm{p}<0,001$

In 2017 was found the significant decrease in hospitalized patients in palliative care wards with the diagnoses as follows: tumours (APC -22.9\%), mental and behavioural disorders (APC -4.6\%), disorders of nervous system (APC -26.3\%), skin and subcutaneous tissue diseases (APC -35.1\%), respiratory disorders (APC -35.4\%), shoulder and arm fractures (APC -25.6\%), multiple area injuries (APC -54, $5 \%$ ) and later consequences of lower limb injuries (APC $-58.3 \%$ ), further was found significant increase in hospitalized patients with the diagnoses as follows: somnolence, sopor and coma (APC $29.7 \%$ ), injuries, poisoning and some other external causes ( APC $10.9 \%$ ), spinal and pelvic fracture (APC $19.7 \%$ ), femur fracture (APC $11.7 \%$ ), complication caused by inner ortho prosthesis (APC $66.7 \%$ ) and aftereffects of head injury (APC 84.6\%) (Tab 1).

The most common diagnosis in hospitalized patients in the palliative care ward were mental and behavioural disorders (2016: $\mathrm{n}=3,639$ of hospitalized patients; 2017: 3,472 of hospitalized patients) with a significant decrease in APC in 2017 by $-4.6 \%$ (Tab.1)

Tab. 2 Analysed analgesics and variables 2016-2017

\begin{tabular}{|c|c|c|c|c|}
\hline \multicolumn{2}{|r|}{ Analysed analgesics and variables } & 2016 & 2017 & $\operatorname{APC}(\%)$ \\
\hline \multirow{3}{*}{$\begin{array}{l}\text { Acetyl- } \\
\text { salicylic acid }\end{array}$} & $\begin{array}{l}\text { Prescription of analgesics by geriatrics } \\
\text { (n) }\end{array}$ & 3618 & 3321 & $-8,2^{*}$ \\
\hline & $\begin{array}{l}\text { Average yearly surcharge by a patient } \\
\text { for } 1 \text { patient }(€)\end{array}$ & 1,14 & 1,40 & $23,1^{*}$ \\
\hline & $\begin{array}{l}\text { Average yearly surcharge of insurance } \\
\text { company for } 1 \text { patient }(€)\end{array}$ & 2,00 & 1,73 & $-13,6^{*}$ \\
\hline Diclofenac & $\begin{array}{l}\text { Prescription of analgesics by geriatrics } \\
\text { (n) }\end{array}$ & 307 & 298 & $-2,9$ \\
\hline
\end{tabular}




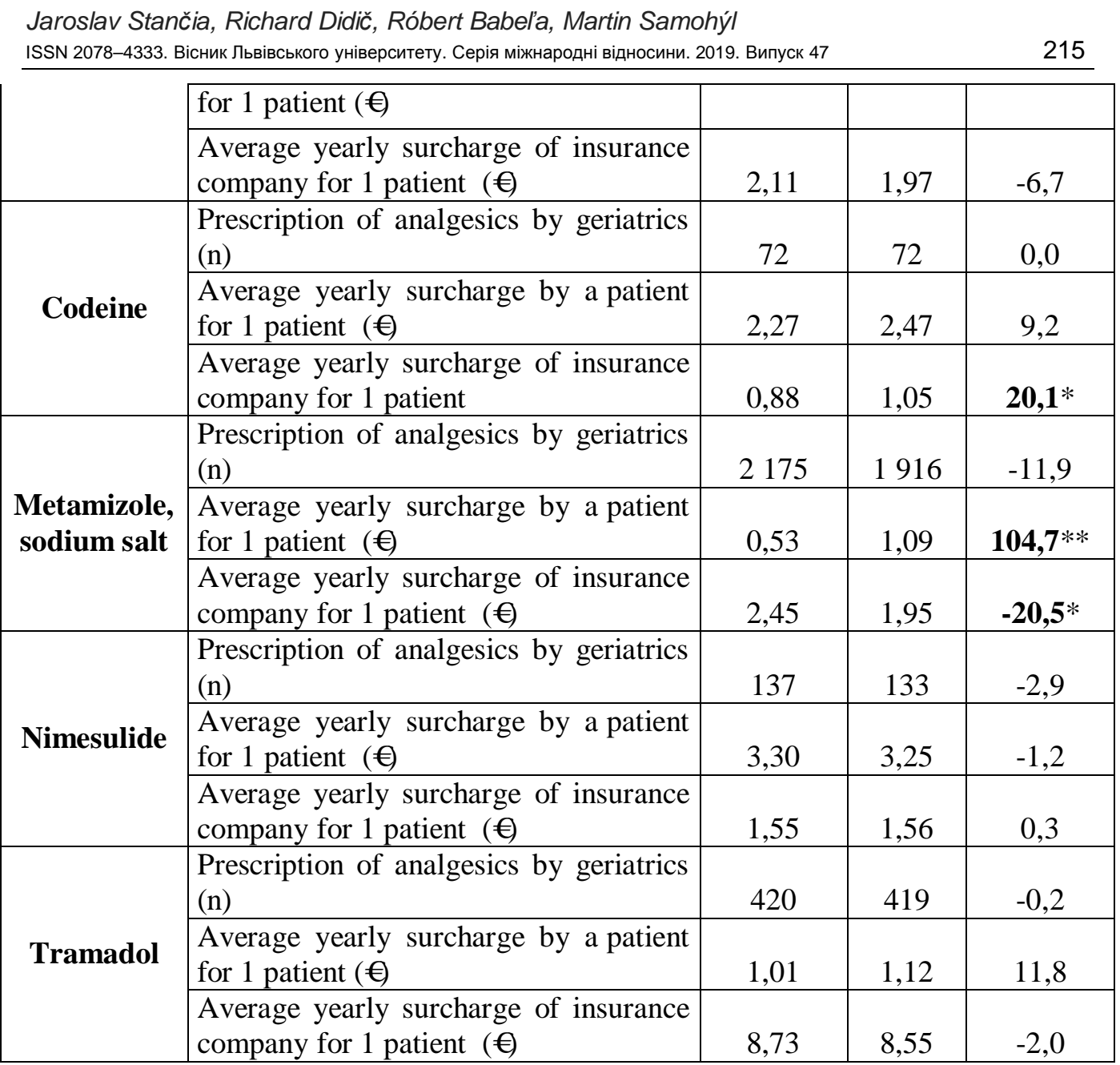

$* \mathrm{p}<0,05 ; * * \mathrm{p}<0,001$

\section{Discussion}

As mentioned at the beginning, the population has been aging, increases the prevention of chronic diseases in the context ofincreasing amount of productive age population. Palliative care is the part of care for vulnerable population. Dementia plays a significant role in palliative care for geriatric patients (O'Brien, 2013).

In our sample dominated mental andbehavioural disorders in the aetiology of patient care at palliativecare ward,in average it reached up to $16.6 \%$ of hospitalizations in the reported period. Foreign literature indicates that up to $40 \%$ of all deaths in the USA appearin sanatoriums, where death by itself is not a psychiatric diagnosis, but over $59 \%$ of terminally ill patients with cancer had depressive syndrome developed (Bailyn et al., 2003). Allegri et al. (2006) reports that geriatric age is the risk for the development of dementia, where the disease affects the individual, family, carers and whole society from social and economic view.

The prevalence of cardiovascular disease in the elderly is increasing as the natural pathologic mechanisms of particular diseases. 
In our sample, during the monitored period, were $4.78 \%$ of all hospitalizations due to cardiovascular and respiratory diseases, the most of the cases were due to cardiac failures (1.97\% of all hospitalizations in the monitored period), chronic ischemic disease $(1.19 \%)$ and subsequently due to vascular diseases of the central nervous system. Thus, cardiovascular diseases significantly burden not only the patients themselves but also their families in the context of anxiety, depression, physical disability and social harm due to health impairments, problems with symptoms and complex care regimes (Braun et al., 2016).

Palliative care is defined as patient and family centred care that optimizes the quality of life associated with health, anticipation, prevention and treatment of suffering, that should be integrated into the care of all patients with advanced CVD and stroke at an early stage of their disease (Braun et al., 2016).

Fractures are a common problem in elderly patients, a 50-year-old woman has a $40 \%$ chance of spinal fracture in her life. The incidence of vertebral fractures is 10 times more common compared to femoral fractures, the vertebral fragments are often observed to occur without a fall history, but femoral fractures are often associated with falls (Tsuda, 2017).

The incidence of vertebral fractures increases in women over 50 years of age, and the same trend as the prevalence of osteoporosis (Tsuda, 2017). On the contrary, the average age for proximal fractures of the femur is about 80 years of age and over $75 \%$ of femoral fractures occur in individuals over 75 years of age (Tsuda, 2017).

The femur injuries and fractures (about $3.5 \%$ of all hospitalizations in the reported period), head injuries (in average $0.12 \%$ of all hospitalizations in the monitored period) and complications caused by inner ortho prostheses (in average $1.7 \%$ of all hospitalizations in the monitored period), implant and transplant were other important elements of palliative care (on average $0.56 \%$ of all hospitalizations in the monitored period).

Fall prevention and prophylactic treatment of osteoporosis is the base for prevention and safeguarding of active aging.

The aftercare and rehabilitation of patients after a hip fracture is connected with different procedures aimed to achieve and maintain maximum functional capacity and quality of life, as the prerequisite for optimal functionality with the maximum independence of geriatric patients (Radosavljevic, 2014).

In the case of monitoring the prescription of analgesics, we can state as follows:

The average annual surcharge of the patient was significantly higher for the surcharge for acetylsalicylic acid and metamizole, the average annual surcharge of the insurance company for one patient was significantly higher for the codeine surcharge and significantly lower for the metamizole surcharge in 2017 compared to 2016.

Sharing the healthcare costs is the significant adherence aspect of the patient treatment and thus the overall quality of life (Toyama et al., 2004).

Metamizole is a frequently prescribed medication for geriatric patients primarily intended for the treatment of pain, followed by atypical opiates and then NSAIDs.

The average yearly surcharge of a patient and the insurance company was not only influenced by categorization, but also by other factors such as price, margin, place 
(pharmacy) where the patient bought the analgesics, seasonality of prescription, adjusted amount of surcharge and others.

Affordable as well as adequately targeted therapy for elderly patients is the essential to improve their quality of life and reduce poly-pragmasia and polypharmacotherapy.

\section{Conclusion}

The aging of the population brings a great challenge to ensure the adequate financial, human and other material resources to ensure the sufficient economic productivity and promote the status of active aging in the context of human dignity and fundamental principles of humanism that should not disappear from our society.

Based on the above mentioned can be seen, that the aging of population requires the training of fully-fledged social and health care workers, who dispose multidimensional knowledge of social work, public health, medical unions, nursing, as well as the law and rights to tackle the issues in the complex context to gain the mentioned goals.

\section{BIBLIOGRAPHY}

1. ALLEGRI, Ricardo F., Judith BUTMAN, Raúl L. ARIZAGA, Gerardo MACHNICKI, Cecilia SERRANO, Fernando E. TARAGANO, Diego SARASOLA a Leandro LON. Economicimpact of dementia in developingcountries: anevaluation of costs of Alzheimer-type dementia in Argentina. International Psychogeriatrics [online]. 2007, 19(04) [cit. 2019-02-24]. DOI: 10.1017/S1041610206003784. ISSN 1041-6102. Dostupné z: http://www.journals.cambridge.org/ abstract_S1041610206003784.

2. BABEL'A et al., Ekonomicé hodnotenie v systéme zdravotnej starostlivosti, Viapract., 2008, roč. 5 (6): 270-271, SSN 1339-424X (online).

3. BLAHA, VAŇO, Prognóza vývoja obyvatel'stva SR do roku 2025 (aktualizácia), 2007 (C) INFOSTAT - Inštitút informatiky a štatistiky Bratislava.

4. BAILYN, R, RUBIN, J, PsychiatricTreatmentChallenges at the End of Life, The CLINICAL VIEW GeriatricPsychiatry in Long-Term Care, 2003.

5. BRAUN, Lynne T., Kathleen L. GRADY, Jean S. KUTNER, et al. PalliativeCare and CardiovascularDisease and Stroke: A PolicyStatementFromthe American Heart Association/American Stroke Association. Circulation [online]. 2016, 134(11) [cit. 2019-02-24]. DOI: 10.1161/CIR.0000000000000438. ISSN 0009-7322. Dostupné z: https://www.ahajournals.org/doi/ 10.1161/CIR.0000000000000438.

6. O'BRIEN, Tony. TheImpact of anAgingPopulation on PalliativeCare. Journal of Pain\&PalliativeCarePharmacotherapy [online]. 2013, 27(4), 389-391 [cit. 2019-02-24]. DOI: 10.3109/15360288.2013.847517. ISSN 1536-0288. Dostupné z: http://www.tandfonline.com/doi/full/ $10.3109 / 15360288.2013 .847517$.

7. RADOSAVLJEVIC, N., NIKOLIC, D., LAZOVIC, M., \& JEREMIC, A. (2014). Hipfractures in a geriatricpopulation - rehabilitationbased on patientsneeds. Aging and disease, 5(3), 177-82. doi:10.14336/AD.2014.0500177.

8. TOYAMA G., FONT C., DoesCostSharingAffecttheQuality of PharmaceuticalCarefortheElderl, HEDG WorkingPaper 09/04, March 2009 ISSN 1751-1976.

9. EUROSTAT, People in the EU - populationprojectionshttps://ec.europa.eu/eurostat/statisticsexplained/index.php/People_in_the_EU_-_population_projections\#Population_projections.

10. http://www.publichealthnotes.com/daly-disability-adjusted-life-years/ - poslednýprístup 10.02.19, 10:05).

11. JAKAB, Z. TheFuture of HealthCare in Europe., 2011. www.euro.who.int. http://www.euro. who.int/_data/assets/pdf_file/0010/135586/RD_speech_Economist_20110317.pdf. 
12. JURENKA, R., A. STARECEK, N. VRANAKOVA a D. CAGANOVA. The Learning Styles of the Generation Group Z and TheirInfluence on Learning Results in the Learning Process. In: 2018 16th International Conference on EmergingeLearning Technologies and Applications (ICETA) [online]. IEEE, 2018, 2018, s. 251-260 [cit. 2019-02-24]. DOI: 10.1109/ICETA.2018.8572186. ISBN 978-1-5386-79142. Dostupné z: https://ieeexplore.ieee.org/document/8572186/.

13. OECD LifeExpectancy. data.oecd.org. - https://data.oecd.org/healthstat/life-expectancy-atbirth.htm (accessed17.01.19, 20:32).

14. ONDRUŠ et al., Medzinárodné verejné zdravotníctvo, 2015, ISBN 978-80-971965-4-7.

15. podl'a http://www.publichealthnotes.com/daly-disability-adjusted-life-years/ - posledný prístup 10.02.19, 10:05).

16. STARECEK, A., M. BEDNARIKOVA, K. KOLTNEROVA, N. VRANAKOVA, Z. GYURNAK BABELOVA, D. CAGANOVA a A. CHLPEKOVA. The Level of CognitiveAbilities of Generational Group Y and EducationalProcess. In: 2018 16th International Conference on EmergingeLearning Technologies and Applications (ICETA) [online]. IEEE, 2018, 2018, s. 511-518 [cit. 2019-02-24]. DOI: 10.1109/ICETA.2018.8572200. ISBN 978-1-5386-7914-2. Dostupné z: https://ieeexplore.iee.org/document/8572200/.

17. STAREČEK, Augustín, Milan BACHÁR, Natália HORŇÁKOVÁ, Dagmar CAGÁŇOVÁ a Helena MAKYŠOVÁ. TRENDS IN AUTOMATIC LOGISTIC SYSTEMS AND LOGISTIC MARKET IN SLOVAKIA. Actalogistica [online]. 2018, 5(1), 7-14 [cit. 2019-02-24]. DOI: 10.22306/al.v5i1.84. ISSN 13395629. Dostupné z: https://www.actalogistica.eu/issues/2018/I_2018_02_Starecek_ Bachar_Hornakova_Caganova_Makysova.pdf.

18. SUZMAN R, BEARD J. Globalhealth and aging: preface. National Institute on Agingwebsite. www.nia.nih.gov/research/publication/global-health-and-aging/preface. PublishedOctober 2011. Updated January 22, 2015. Accessed August 1, 2015.

19. TSUDA T. (2017). Epidemiology of fragilityfractures and fallprevention in theelderly: a systematicreview of theliterature. Currentorthopaedicpractice, 28(6), 580-585.

20. WHO, GlobalHealth and Aging - WHO , NIA, NIH, U.S. Department of Health and Human Services, 11-7737 October 2011, dostupné na: https://www.who.int/ageing/publications/ global_health.pdf

21. WHO, Global status report on noncummunicabledisease 2014 ISBN 978924156485 4, WHO 2014.

22. WHO, https://www.who.int/gho/ncd/mortality_morbidity/en/, posledný prístup 3.2.19 - 23:25.

23. WHO, https://www.who.int/mental_health/management/depression/daly/en, 2018.

24. WHO, Global status report on noncommunicablediseases 2010, ISBN 9789240686458 (PDF).

Стаття надійшла до редколегії 30.08.2019 Прийнята до друку 10.09.2019

\title{
ДЕМОГРАФІЯ ТА ОХОРОНА ЗДОРОВ’Я В ПАЛІАТИВНІЙ СИСТЕМІ
}

\author{
Ярослав Станчя \\ Університет Коменського в Братиславі, педагогічний факультет \\ Річард Дідіч, Роберт Бабеля \\ Інститут дисииплін охорони здоров'я, Університет Св. Слизавети, Братислава
}

\section{Мартін Самогіл}

Університет Коменського в Братиславі, Інститут гігієни, медичний факультет

Мета нашої роботи - проаналізувати тенденції госпіталізації у відділення паліативної допомоги та тенденції вживання знеболюючих препаратів, призначених геріатрією. 
Jaroslav Stančia, Richard Didič, Róbert Babel'a, Martin Samohýl

ISSN 2078-4333. Вісник Львівського університету. Серія міжнародні відносини. 2019. Випуск 47

Проаналізовано споживання 21302 найпоширеніших діагнозів у госпіталізованих пацієнтів у палати паліативної допомоги у період з січня 2016 до грудня 2017. Дані базувалися на запиті, наданому Všeobecnázdravotnápoist’ovňa, a.s. (медична страхова компанія). Для аналізу використано APC (річний показник процентних змін), а для статистичного аналізу - IBM SPSS Statistics. Проаналізовано вживання 12888 найчастіше призначених анальгетиків у геріатрії у період з січня 2016 до грудня 2017. Виявлено зменшення кількості госпіталізованих хворих у відділеннях паліативної допомоги з діагнозами: пухлини (АРС - 22,9\%), психічні та поведінкові розлади (АРС - 4,6\%), розлади нервової системи (АРС - 26,3\%), захворювання шкіри та підшкірної клітковини (АРC - 35,1 \%), розлади дихання (АРC - 35,4 \%), переломи плечей та рук (АРС - 25,6 \%), множинні травми ділянок (АРС - 54, $5 \%$ ) та пізніші наслідки травм нижніх кінцівок (АРС 58,3\%) 2017 року. Старіння населення представляє велику проблему для забезпечення належних фінансових, людських та інших матеріальних ресурсів, для забезпечення достатньої економічної продуктивності та сприяння статусу активного старіння в контексті людської гідності та основних принципів гуманізму, які не повинні зникати у суспільстві.

Ключові слова: демографія; неінфекційні хвороби; паліативна допомога; старіння населення; охорона здоров'я. 